\title{
MAPPING PROTECTED AREAS BY GIS METHOD: A CASE STUDY OF IZMIR CITY, ÇEŞME DISTRICT (TURKEY)
}

\author{
ANKAYA, F. ${ }^{1}-$ TÜRKYILMAZ, B. $^{2}-$ KÖSE, H. $^{3}$ \\ ${ }^{1}$ Alaşehir Vocational School, Manisa Celal Bayar University, Alaşehir-Manisa, Turkey \\ (e-mail: fundaunalankaya@hotmail.com; phone: +90-531-425-3407; fax: +90-236-654-1200) \\ ${ }^{2}$ Department of Landscape Architecture, Faculty of Agriculture, Ege University, Izmir, Turkey \\ (e-mail: turkyilmaz.bahar@hotmail.com; phone: +90-533-660-5740) \\ ${ }^{3}$ Alaşehir Vocational School, Manisa Celal Bayar University, Alaşehir-Manisa, Turkey \\ (e-mail: mhkose@yahoo.com; phone: +90-534-612-7077) \\ *Corresponding author \\ e-mail: fundaunalankaya@hotmail.com
}

(Received 24 $4^{\text {th }}$ Jul 2019; accepted 25 ${ }^{\text {th }}$ Nov 2019)

\begin{abstract}
In Turkey, in order to protect nature, there are strategies and categories depending on differences between local environmental conditions as in many countries in the world. The term of "protected environments", is also supported by laws as in other countries around the world. Natural protected environments are divided into the following three categories "Critical Environments under the Protection of Law" (SAPUL), "Natural Protected Environments with Qualifications" and "Sustainable Protection and Controlled Usage Environments", according to the resolution Conditions of Protection and Use of Natural Protected Environments, dated 2017, of Turkish Republic Ministry of Environment and Urban Planning. A map of Natural Protected Environments has been generated as a result of evaluation of 81 polygons which have been specified as natural protected environment borders by the Protection Commission of the Turkish Republic Ministry of Environment and Urban Planning, the strategy for determining (SAPUL) is approached as this article's subject. According to this strategy, in Çeşme (Izmir/Turkey) district, 20 polygons were specified to belong to the categories (SAPUL) among 81 polygons based on the terms and definition of the resolution of Izmir City and Çeşme district. Borders of natural protected environments, which were specified by the protection commission of the Turkish Republic Ministry of Environment and Urban Planning, each polygon is generated based on up-to-date land use information, have been formed based on the visuals taken from IKONOS satellite in 2017. The natural areas that carry the status of SAPUL were specified based on the specifications of the landscape and criteria of landscape assessment as the "use of the land", "live natural landscape", "historical landscape", Hereat, each polygon has been evaluated and mapped according to their specifications of landscape. Primarily, sample map has been created by using quantitative evaluation, which is supported by geographical information system (GIS). It is thought that this strategy will be useful for the resolutions that will be taken by the Committee on Conservation of Cultural Assets in Turkey in the Ministry of Environment and Urban Planning.
\end{abstract}

Keywords: natural protected areas, Çeşme Peninsula, İzmir City, Çeşme District, environments under the protection of the law, GIS

\section{Introduction}

In general, when the topic is about the protection of nature the following factors are considered: plants, animals, their environment where they grow and live and some pieces of nature which are thought to be valuable according to some criteria for the guarantee of human life (Caner, 2007; Yücel, 1995). Protection of nature covers protection of wild animals, varieties of plants, their natural living environments, securing landscapes with natural conditions, pieces of landscape and protective 
measurements (Çolak, 2001). The term of protection is shorty and newly defined as; the usage of the Earth's sources in a rationalist way (Mac Kinnon et all., 1986). The term "natural protected area", which is the main topic of this research, is known under different names in different countries. According to Gülez (1984) natural protected areas are defined as the environments that have topographical, hydrologic, biological, aesthetics- perceptive, cultural-historical values. In general, the environments that have historical and natural beauty, are considered as natural protected areas (Mumcu, 2009; Yenilmez Arpa, 2016). Nowadays, in so many countries, the necessity of protection of the inherited natural protected areas is accepted at national level. Thus, every nation participates in protecting biological diversity and resources with their own affords (Türkyılmaz, 1991).

Çesme District which is the research zone, is located in west of Anatolia and was a port town known as Ildiri. This port town was a part of Erythrai which was one of 12 Ion cities B.C. 1000. Erythrai was a very important city in $6^{\text {th }}$ century B. C. Erythrai had good relations with Cyprus, Egypt and some western countries and developed its trade routes. Çeşme was under the rule of Persians, Romans and Byzantium.

It is important to determine the characteristics of the area before taking it under protection because the land should have some required characteristics to be under the protection (Özer, 2004; Buchwald, 1980; Heydemann, 1981; Mac Kinon, 1986; Green, 1985; Yücel, 1995; Yazıc1 et al., 2017). The strategies of evaluation and classification of the lands must suit to three conditions;1) The strategy must be understandable for the planners, 2) Local people must take advise from naturalists, 3) Rational goals should be set to overcome the legal barriers (Frederic et al., 1988). Different kinds of grades are given to the areas according to the different criteria in the system of identifying priority of natural protection (Mackinnon et al., 1986). There are some measurements to specify and categorize the natural protected areas. Those measurements should be set with bioecologic (flora, fauna, habitat), geological, hydrogeological, geomorphologic characteristics of the landscape. In the evaluation made by the Ministry of Environment and Urban Planning in terms of specifications of landscape, it is considered if the field has the natural characteristics, manmade or not and it was supported by GIS. GIS is a database where bulky geographical data is collected, stored and processed. The data in GIS helps users during the period of decision for areas/locations to prevent planing problems of complex social, economic, enrivonmental problems (Yazic1 et al., 2017; Yazıc1 and Gülgün, 2018a). Geographical Information System is an important support base for the protection of natural protected areas (Yazic1 et al., 2018b).

\section{Materials and methods}

Çesme District, which has cultural values, is one of the tourist centers of our country as well as of the world. Therefore, it is needed to be managed effectively in order to keep the sustainability of natural and cultural values. The main material of the research is the research field. Research field Izmir city (Turkey) Cesme district (Fig. 1).

Cesme, is one of the districts of Izmir, it is located in the west of the country, in the Aegean Region, in the southwest of the Karaburun Peninsula. Cesme district is $94 \mathrm{~km}$ away from Izmir city at 38.32 North latitude and 26.30 East longitudes. The district is surrounded by Urla district in the east Karaburun district in the north, and the Aegean Sea in west and south. Square measure of Cesme district is $260 \mathrm{~km}^{2}$. Cesme has one town (Alaçatı) and four villages. According to the census in 2017, the district has a 
population of 41.278 (Anonymous, 2019b) However during the summer/tourism period it increases more than 20 times. Tourism designate the economic structure. Cesme is one of the few places in Turkey that are domestic and international tourism centers.

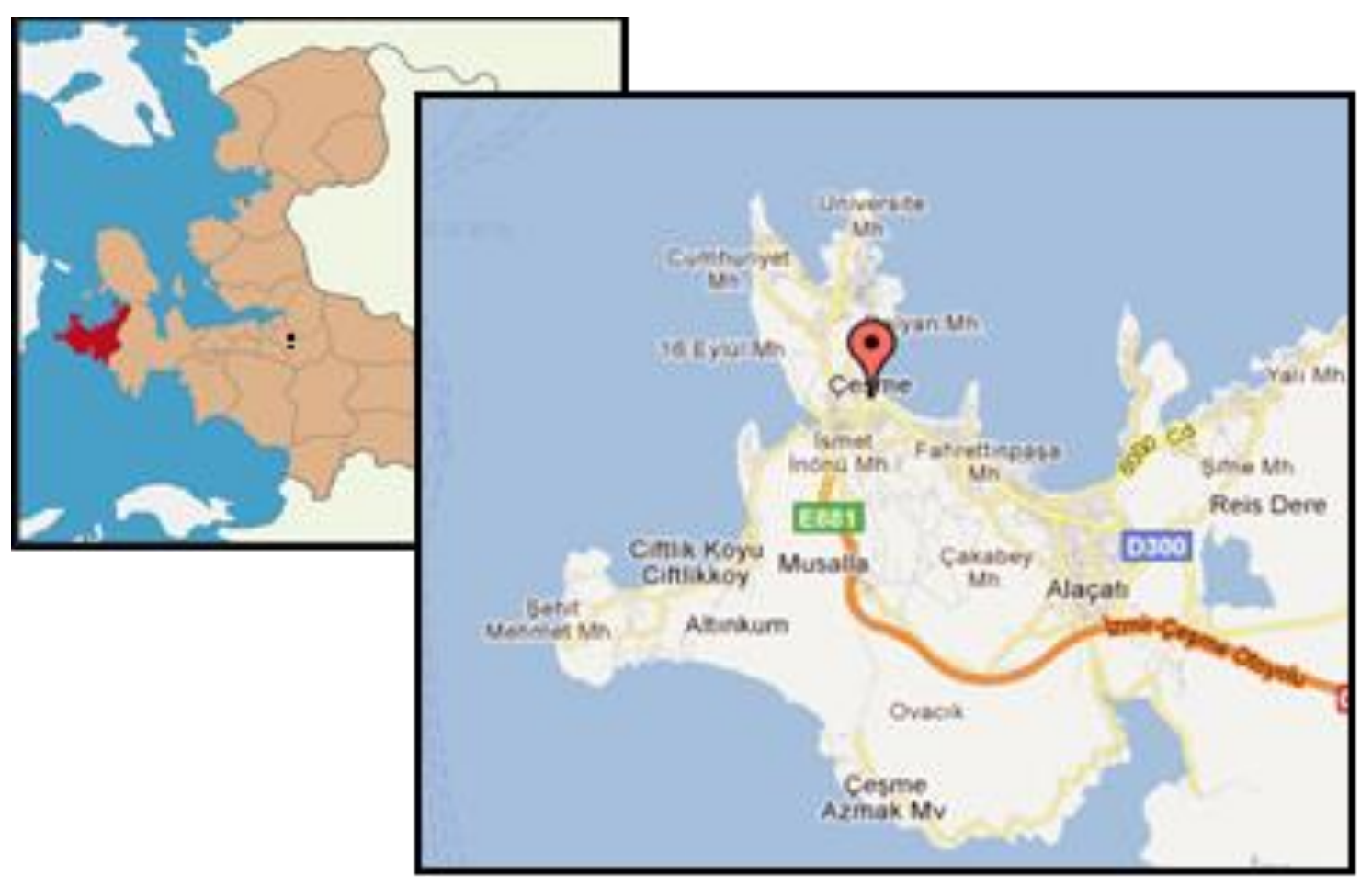

Figure 1. Cesme district general layout (Anonymous, 2019a)

\section{Material}

Main materials of the research are research field (Cesme District) images taken from Ikonos satellite in 2017, image analyst (Intergraph) program, 1/25000 scale map of current natural protected area, 1/25000 scale map of Cesme District's topographic map and Microstation (Bentley) program that provides the geometrical corrections, Geomedia 6.0 program, Ipad Air tablet. Table 1 shows the distinguishing specifications of "SAPUL" based on the conditions of Natural protected areas resolution dated 2017 by the Ministry of Environment and Urban Planning. In this chart, the explanations of "yes", "no", "partly" are quantitatively interpreted according to the specialists' opinions and evaluations. Specifications such as being organic, inorganic, historical, renewable and sensitive, specified 20 polygons out of 81 in the category of "SAPUL" (Fig. 2) based on the terms and definition of resolution of Izmir City, which was considered while scoring as seen in Tables 3-7. The methods in research studies of Green (1985), Mackinnon et al. (1986), Gülez (1990), Türkyılmaz (1991, 2005) and Uzun and Müderrisoğlu (2010) have been used while evaluating the specifications of the landscape. 


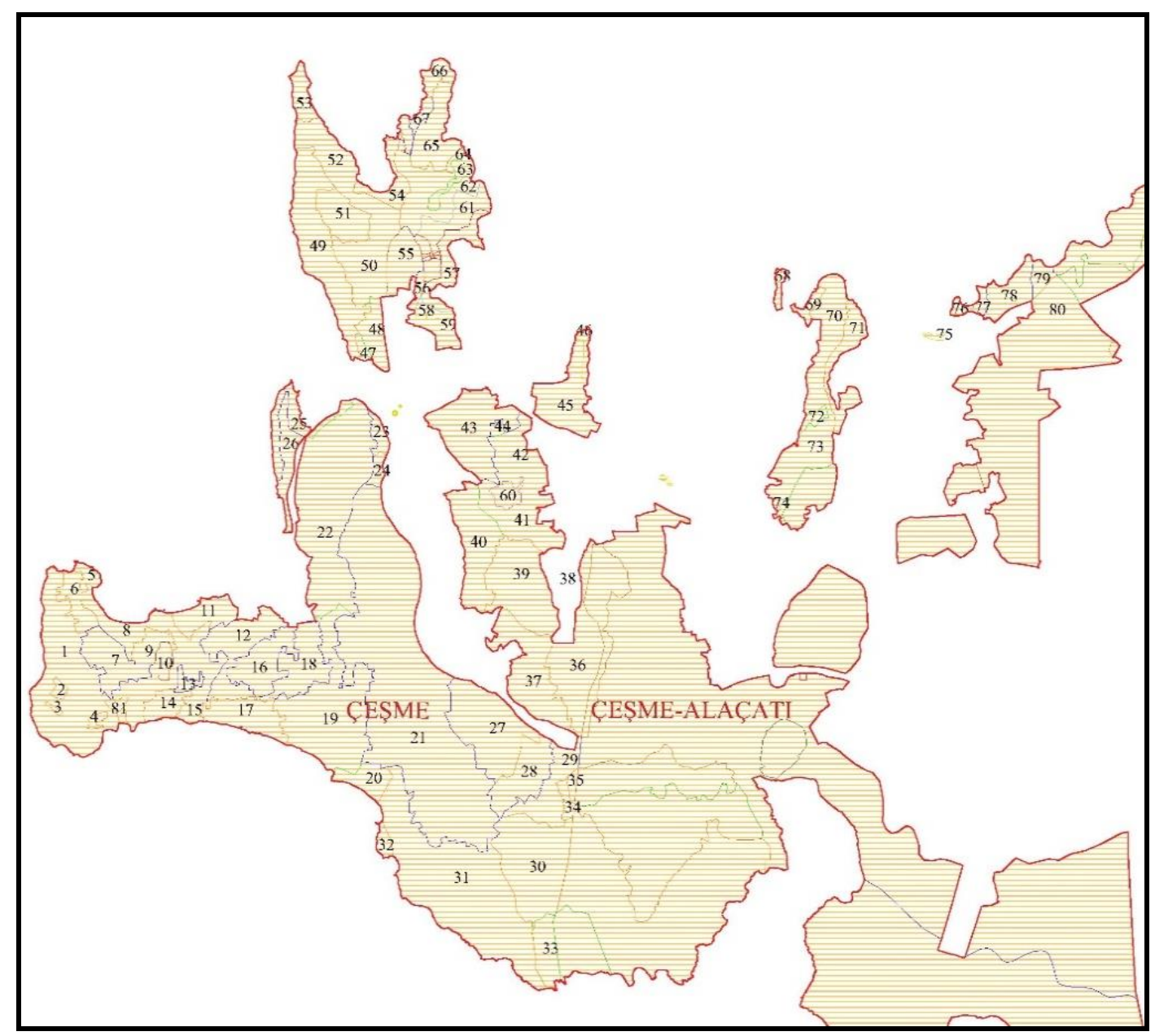

Figure 2. Borders of natural protected area polygons determined by Protection Commission of Cesme District. (The numbers seen in the figure, were given by the researchers so the polygons in Figure 2. shown in the map could be evaluated. Those numbers are used in Table 15 to create the result map)

\section{Method}

The research method was designed with the stages shown below.

First Stage: 6 tables, which show specifications of evaluation the research field, have been created in consideration of Table 1 and each chart has been graded based on the matrix method in itself.

In the second stage, the materials, which show the distinguishing specifications, are questioned in consideration of Table 2. Border of cultural natural protected area polygons and status of each polygon given by protection commission was adapted with the grading method in the first stage. Qualitative evaluation such as "yes", "no", "partly" was quantified with GIS in order to create natural protected area map in terms of specifications of landscape.

The evaluating method has been approached based on the explanations given in Table 2.

Each polygon, which generates the map shown in Figure 2, was digitalized by using Ikonos satellite images with GIS program so the specifications of land use plan have been stated. 
The land use map has been classified in four fields. These are:

1. Residential area

2. Agricultural areas

3. Tarsius spectrum + Garrigue + Forest areas

4. Litosolig + Garrigue areas

Table 1. Distinguishing specifications of "environments under the protection of the law

\begin{tabular}{|c|c|c|c|c|c|}
\hline \multicolumn{2}{|r|}{$\begin{array}{l}\text { Distinguishing specifications of "environments under } \\
\text { the protection of the law" }\end{array}$} & \multirow{2}{*}{$\begin{array}{c}\text { Yes } \\
12-13-14\end{array}$} & \multirow{2}{*}{$\begin{array}{l}\text { No } \\
7-8\end{array}$} & \multirow{2}{*}{$\begin{array}{c}\text { Partly } \\
9-10-11\end{array}$} & \multirow{2}{*}{\begin{tabular}{|c|}
$\begin{array}{c}\text { Opinions and evaluations of } \\
\text { specialists }\end{array}$ \\
Evaluated based on the \\
specifications of organic \\
natural landscape (Table 3)
\end{tabular}} \\
\hline $\mathrm{a}$ & $\begin{array}{l}\text { They have regional, national and global extraordinary } \\
\text { ecosystems and species }\end{array}$ & & & & \\
\hline $\mathrm{b}$ & Specifications of geologic, geomorphologic & $7-8-9$ & $2-3$ & $4-5-6$ & $\begin{array}{c}\text { Evaluated based on the } \\
\text { specifications of Inorganic } \\
\text { natural landscape (geologic- } \\
\text { Table 4) }\end{array}$ \\
\hline $\mathrm{c}$ & In general, came to existence without human effect & $2-3-4$ & $-2-(-3)$ & $-1-0-1$ & $\begin{array}{l}\text { Evaluated based on the } \\
\text { specifications of cultural } \\
\text { landscape }\end{array}$ \\
\hline d & $\begin{array}{c}\text { Because of human effect, it is under the risk of } \\
\text { perishment }\end{array}$ & $6-7-8$ & $1-2$ & $3-4-5$ & $\begin{array}{c}\text { Evaluated based on the } \\
\text { specifications of organic } \\
\text { natural landscape (sensitivity } \\
\text { Table 7) }\end{array}$ \\
\hline $\mathrm{e}$ & $\begin{array}{l}\text { The area does not contain human effect which is } \\
\text { against its protection targets }\end{array}$ & $\begin{array}{l}18-19-20- \\
21-22 \\
\text { (historical } \\
\text { landscape) }\end{array}$ & $9-10-11$ & $\begin{array}{l}12-13-14-15- \\
16-17 \\
\text { (historical } \\
\text { landscape) }\end{array}$ & $\begin{array}{c}\text { Evaluated based on the } \\
\text { specifications of } \\
\text { (organic + inorganic) + histori } \\
\text { cal landscape If there is } \\
\text { touristic area, it is mentioned } \\
\text { (Tables 3-5) }\end{array}$ \\
\hline $\mathrm{f}$ & $\begin{array}{l}\text { It contains large percentage of the local species that is } \\
\text { expected to exist. It has the ability to transform itself } \\
\text { to the intensity with natural process or limited } \\
\text { interferences }\end{array}$ & $\begin{array}{l}19-20-21- \\
22-23-24\end{array}$ & $10-11-12$ & $\begin{array}{l}13-14-15-16- \\
17-18\end{array}$ & \begin{tabular}{|c} 
Evaluated based on the \\
specifications of (Natural \\
organic landscape \\
+ renewable ability) (Tables 3 \\
and 6) \\
\end{tabular} \\
\hline $\mathrm{g}$ & $\begin{array}{l}\text { In order to reach the aim of protection it has very vital } \\
\text { and continuous interference }\end{array}$ & $\begin{array}{l}25-26-27- \\
28-29-30- \\
31-32\end{array}$ & $12-13-14-15$ & $\begin{array}{l}16-17-18-19- \\
20-21-22-23- \\
\quad 24\end{array}$ & $\begin{array}{c}\text { Evaluated based on the } \\
\text { specifications of (Natural } \\
\text { organic landscape }+ \text { ability to } \\
\text { renew itself + Natural } \\
\text { inorganic landscape (Tables 3, } \\
4 \text { and } 6 \text { ) }\end{array}$ \\
\hline $\mathrm{h}$ & $\begin{array}{l}\text { It is surrounded by the use of areas that will help the } \\
\text { area to reach the aims of protection when it is possible } \\
\text { and necessary }\end{array}$ & & & & $\begin{array}{c}\text { It has been evaluated based on } \\
\text { the natural zone around the } \\
\text { polygon }\end{array}$ \\
\hline 1 & $\begin{array}{l}\text { It could be managed by application of simple } \\
\text { interference }\end{array}$ & $8-10$ & $3-4$ & $5-6-7$ & $\begin{array}{c}\text { It has been interpreted based } \\
\text { on the ability to renew itself } \\
\text { (Table 6) }\end{array}$ \\
\hline $\mathrm{i}$ & $\begin{array}{l}\text { It contains the reproduction area for the species that } \\
\text { are aimed to be protected }\end{array}$ & & & & $\begin{array}{c}\text { It has been evaluated based on } \\
\text { the floristic evaluation report } \\
\text { of the area }\end{array}$ \\
\hline
\end{tabular}

Table 2. Evaluation of acreage of the specifications of land use in polygons, which belong to "the natural areas protected under law" (SAPUL)

\begin{tabular}{c|c|c|c|c}
\hline Polygon No & Status of natural protected areas & Land use & Area $\left(\mathbf{m}^{2}\right)$ & Area $(\%)$ \\
\hline & (SAPUL) & 1 & & \\
& (SAPUL) & 2 & & \\
& (SAPUL) & 3 & & \\
& (SAPUL) & 4 & & \\
\hline & & Total & & $\mathbf{1 0 0 . 0 0}$ \\
\hline
\end{tabular}


Cultural Landscape values of suitability, levels of suitability and abbreviations:

\begin{tabular}{c|c|c}
\hline Suitability value & Suitability level & Abbreviation \\
\hline 4 & Most suitable & M.S. \\
3 & Suitable & S. \\
2 & Partial suitable & P.S \\
1 & Less suitable & L.S. \\
0 & Least suitable & Lea. S. \\
-1 & Not suitable & N.S \\
-2 & Partially not suitable & P.N.S \\
-3 & Not suitable at all & N.S. \\
\hline
\end{tabular}

Cultural landscape values of suitability in Tables 3-7 have been set after considering the percentage of the 1 (residential) and 2 (agricultural) areas specifications. According to the given information in Table 2, if there is no residential area in the polygon the following calculations have been used; $[(<1 \%)$ the least suitable] was given " 0 " point, if percentage of area $(\%)$ reached [(\%1-33); not suitable] it was given "-1" point, if percentage of the area (\%) reached [(\%34-66); Partially not suitable] it was given "-2" points, if percentage of area (\%) reached [(67-100\%); Not suitable at all.] it was given "-3"points. According to the given information in Table 2, if there is no agricultural area in the polygon the following calculations have been used; [(<\%1) The most suitable] "4" points were given, if the percentage of the area $(\%)$ reached [(1-33\%); Suitable] " 3 ”points were given, if percentage of the area (\%) reached [(34-66\%)]; Partial suitable] " 2 " points were given, if the percentage of the area (\%) reached [(67-100\%); Less suitable] "1"point was given. Thus, cultural landscape values of suitability have been set. 81 polygons have been evaluated separately by using GIS and 20 polygons have been determined as the areas will be under protection. Thus, the map of suggested natural protected areas has been created in Table 15 and Figure 10.

Below it has been defined how the index values has been created in Tables 3-7.

According to the organic natural landscape index values (Table 3), each polygon is determined after considering the research studies on the field (each polygon has been checked and compared based on the 2017 satellite images and the actual area) and map of land use and listed according to their importance. According to this information; evaluation has been done as the followings. If the area is stony and rocky 1 point is given, if there is a Frigana-Maquis 2 points are given, if there is a forest 3 points are given, if there is an endemic and sensitive area 4 points are given.

Table 3. Combining of qualifications of organic natural landscape index values and cultural landscape of suitability

\begin{tabular}{|c|c|c|c|c|c|c|c|c|c|c|}
\hline \multirow{3}{*}{\multicolumn{2}{|c|}{ Organic natural landscape }} & \multicolumn{8}{|c|}{ Suitability value } & \multirow{3}{*}{ 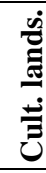 } \\
\hline & & \multicolumn{4}{|c|}{ Residential areas } & \multicolumn{4}{|c|}{ Agricultural areas } & \\
\hline & & $\begin{array}{l}\text { N.S. at all } \\
67-100 \% \\
\end{array}$ & \begin{tabular}{|c|} 
P.N.S \\
34-66\% \\
\end{tabular} & \begin{tabular}{|c|} 
N.S \\
$1-33 \%$ \\
\end{tabular} & \begin{tabular}{|c|} 
\\
Lea.S \\
$<1 \%$
\end{tabular} & $\begin{array}{c}\text { L.S } \\
67-100 \% \\
\end{array}$ & \begin{tabular}{|c|} 
P.S \\
34-66\% \\
\end{tabular} & $\begin{array}{c}\mathrm{S} \\
\mathbf{1 - 3 3 \%} \\
\end{array}$ & $\begin{array}{l}\text { M.S } \\
<1 \% \\
\end{array}$ & \\
\hline \multicolumn{2}{|l|}{ Index value } & -3 & -2 & -1 & $\mathbf{0}$ & 1 & 2 & 3 & 4 & \\
\hline Stony-rocky & 1 & 1 & 1 & 1 & 1 & 1 & 1 & 1 & 1 & \\
\hline Frigana-lemuroid & 2 & 2 & 2 & 2 & 2 & 2 & 2 & 2 & 2 & \\
\hline Forest & 3 & 3 & 3 & 3 & 3 & 3 & 3 & 3 & 3 & \\
\hline Endemic and sensitivity & 4 & 4 & 4 & 4 & 4 & 4 & 4 & 4 & 4 & \\
\hline \multirow{2}{*}{\multicolumn{2}{|c|}{ Total }} & 7 & 8 & 9 & 10 & 11 & 12 & 13 & 14 & \\
\hline & & \multicolumn{2}{|c|}{$\begin{array}{l}\text { "no" scale score } \\
(\text { Table 1) }\end{array}$} & \multicolumn{3}{|c|}{$\begin{array}{l}\text { “partly” scale score } \\
\text { (Table 1) }\end{array}$} & \multicolumn{3}{|c|}{$\begin{array}{c}\text { "yes" scale score } \\
(\text { Table 1) }\end{array}$} & \\
\hline
\end{tabular}


In Table 3 cultural landscape values of suitability points and organic natural landscape index points have been combined and total evaluation points have been created and organic natural landscape points have been created for each polygon.

In Table 4 each polygon has been determined according to the map of land use and has been pointed based on their importance. Thus; Inorganic natural landscape specifications have been set based on the criteria given below.

Elevation from sea level: Accruement of the polygon positively according to sea level " 0 ". It has been evaluated as +1 .

Ascending slope: The map with scale 1/25000 of Cesme district was evaluated and if the landscape has $12 \%$ and above slope, it is accepted that the landscape has an ascending slope and it is estimated as caterpillars cannot be operated on the landscape. (If the slope is $12 \%>$ on the area the caterpillars will not be able to work in the area.

Shore-Edge: The polygons which has edges to shore next to the sea, has been evaluated +1 points.

Dune: The polygons which has edges to shore and has dune areas, has been evaluated +1 points.

Geologic-geomorphologic: If the cultural landscape point is 3 or above, it has been evaluated +1 points.

In Table 4, cultural landscape values of suitability and inorganic natural landscape index points have been combined and evaluation points have been created. Considering this table for each polygon, inorganic natural landscape points have been created (those points can be seen in Table 15).

Table 4. Combining of inorganic natural landscape index values specifications and cultural landscape values of suitability

\begin{tabular}{|c|c|c|c|c|c|c|c|c|c|c|}
\hline \multirow{3}{*}{\multicolumn{2}{|c|}{ Inorganic natural landscape }} & \multicolumn{8}{|c|}{ Suitability value } & \multirow{3}{*}{ 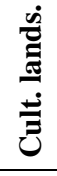 } \\
\hline & & \multicolumn{4}{|c|}{ Residential areas } & \multicolumn{4}{|c|}{ Agricultural areas } & \\
\hline & & $\begin{array}{l}\text { N.S. at all } \\
67-100 \% \\
\end{array}$ & \begin{tabular}{|c|} 
P.N.S \\
34-66\% \\
\end{tabular} & \begin{tabular}{|c|} 
N.S \\
$1-33 \%$ \\
\end{tabular} & $\begin{array}{l}\text { Lea.S } \\
<1 \% \\
\end{array}$ & $\begin{array}{c}\text { L.S } \\
67-100 \% \\
\end{array}$ & \begin{tabular}{|c|} 
P.S \\
$34-66 \%$ \\
\end{tabular} & $\begin{array}{c}\mathrm{S} \\
1-33 \% \\
\end{array}$ & $\begin{array}{l}\text { M.S } \\
<1 \% \\
\end{array}$ & \\
\hline \multicolumn{2}{|l|}{ Index value } & -3 & -2 & -1 & $\mathbf{0}$ & 1 & 2 & 3 & 4 & \\
\hline Height & 1 & 1 & 1 & 1 & 1 & 1 & 1 & 1 & 1 & \\
\hline Slope & 1 & 1 & 1 & 1 & 1 & 1 & 1 & 1 & 1 & \\
\hline Shore-edge & 1 & 1 & 1 & 1 & 1 & 1 & 1 & 1 & 1 & \\
\hline Dune & 1 & 1 & 1 & 1 & 1 & 1 & 1 & 1 & 1 & \\
\hline \multirow[t]{3}{*}{$\begin{array}{c}\text { Geologic- } \\
\text { geomorphologic }\end{array}$} & 1 & 1 & 1 & 1 & 1 & 1 & 1 & 1 & 1 & \\
\hline & & 2 & 3 & 4 & 5 & 6 & 7 & 8 & 9 & \\
\hline & & \multicolumn{2}{|c|}{$\begin{array}{c}\text { "no" scale score } \\
\text { (Table 1) }\end{array}$} & \multicolumn{3}{|c|}{$\begin{array}{c}\text { "partly" scale score } \\
\text { (Table 1) }\end{array}$} & \multicolumn{3}{|c|}{$\begin{array}{c}\text { "yes" scale score } \\
(\text { Table 1) }\end{array}$} & \\
\hline
\end{tabular}

In Table 5, each polygon has been determined according to the observations on the field and considering map of land use. Thus, in addition to the cultural landscape score if there is an urban protected area, it has been evaluated +1 , if there is an archeological protected area it has been evaluated +2 . In Table 5 each polygon has been evaluated separately and historical landscape score has been set up based on combining each index value with the values of suitability that creates cultural landscape by using matrix method. 
In the Table 5, each polygon has been evaluated separately and natural landscape score has been set up based on combining each values of suitability with qualification of use of terrain that creates cultural landscape.

Table 5. Combining of historical landscape specifications index values and cultural landscape values of suitability

\begin{tabular}{|c|c|c|c|c|c|c|c|c|c|c|}
\hline \multirow{3}{*}{ Historical landscape } & & \multicolumn{8}{|c|}{ Suitability value } & \multirow{3}{*}{$\begin{array}{l}\dot{\theta} \\
\dot{E} \\
\dot{E} \\
\dot{E}\end{array}$} \\
\hline & & \multicolumn{4}{|c|}{ Residential areas } & \multicolumn{4}{|c|}{ Agricultural areas } & \\
\hline & & $\begin{array}{l}\text { N.S. at all } \\
67-100 \%\end{array}$ & $\mid \begin{array}{c}\text { P.N.S } \\
\text { 34-66\% }\end{array}$ & $\begin{array}{c}\text { N.S } \\
1-33 \%\end{array}$ & $\begin{array}{l}\text { Lea.S } \\
<1 \%\end{array}$ & $\begin{array}{c}\text { L.S } \\
67-100 \%\end{array}$ & $\begin{array}{c}\text { P.S } \\
34-66 \%\end{array}$ & $\stackrel{S}{1-33 \%}$ & $\begin{array}{l}\text { M.S } \\
<1 \%\end{array}$ & \\
\hline \multicolumn{2}{|l|}{ Index value } & -3 & -2 & -1 & $\mathbf{0}$ & 1 & 2 & 3 & 4 & \\
\hline Urban protected area & 1 & 1 & 1 & 1 & 1 & 1 & 1 & 1 & 1 & \\
\hline Archeological prot. area & 2 & 2 & 2 & 2 & 2 & 2 & 2 & 2 & 2 & \\
\hline & & $\mathbf{0}$ & 1 & 2 & 3 & 4 & 5 & 6 & 7 & \\
\hline & & \multicolumn{2}{|c|}{$\begin{array}{l}\text { "no" scale score } \\
\text { (Table 1) }\end{array}$} & \multicolumn{3}{|c|}{$\begin{array}{c}\text { "partly" scale score } \\
\text { (Table 1) }\end{array}$} & \multicolumn{3}{|c|}{$\begin{array}{c}\text { “yes" scale score } \\
(\text { Table 1) }\end{array}$} & \\
\hline
\end{tabular}

In Table 6, each polygon has been determined according to the observations on the field and considering map of land use. and they are listed based on their importance. Thus, forest areas are determined as 3 points, Frigana-Maquis areas are determined as 2 points and agricultural areas are determined as 1 point in each polygon.

In Table 6, each polygon has been evaluated separately based on combining index values of cultural landscape with values of suitability that has the ability of renewing itself.

Table 6. Combining the ability to renew itself index values and cultural landscape values of suitability

\begin{tabular}{|c|c|c|c|c|c|c|c|c|c|c|}
\hline \multirow{3}{*}{\multicolumn{2}{|c|}{ Ability of renewing itself }} & \multicolumn{8}{|c|}{ Suitability value } & \multirow{3}{*}{ 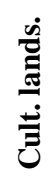 } \\
\hline & & \multicolumn{4}{|c|}{ Residential areas } & \multicolumn{4}{|c|}{ Agricultural areas } & \\
\hline & & $\begin{array}{l}\text { N.S. at all } \\
67-100 \%\end{array}$ & $\begin{array}{c}\text { P.N.S } \\
\text { 34-66\% }\end{array}$ & $\begin{array}{c}\text { N.S } \\
1-33 \%\end{array}$ & $\begin{array}{c}\text { Lea.S } \\
<1 \%\end{array}$ & $\underset{67-100 \%}{\text { L.S }}$ & $\begin{array}{c}\text { P.S } \\
\text { 34-66\% }\end{array}$ & $\underset{1-33 \%}{S}$ & $\begin{array}{l}\text { M.S } \\
<1 \%\end{array}$ & \\
\hline \multicolumn{2}{|l|}{ Index value } & -3 & -2 & -1 & $\mathbf{0}$ & 1 & 2 & 3 & 4 & \\
\hline Forest Area & 3 & 3 & 3 & 3 & 3 & 3 & 3 & 3 & 3 & \\
\hline Frigana-maki & 2 & 2 & 2 & 2 & 2 & 2 & 2 & 2 & 2 & \\
\hline Agricultural area & 1 & 1 & 1 & 1 & 1 & 1 & 1 & 1 & 1 & \\
\hline & & 3 & 4 & 5 & 6 & 7 & 8 & 9 & 10 & \\
\hline & & \multicolumn{2}{|c|}{$\begin{array}{l}\text { "no" scale score } \\
\text { (Table 1) }\end{array}$} & \multicolumn{3}{|c|}{$\begin{array}{l}\text { "partly" scale score } \\
\text { (Table 1) }\end{array}$} & \multicolumn{3}{|c|}{$\begin{array}{l}\text { “yes" scale score } \\
(\text { Table 1) }\end{array}$} & \\
\hline
\end{tabular}

In Table 7, 4 points are added if there are endemic and sensitive areas specifications in organic natural landscape specifications (if there are only endemic or rare species). In Table 7, each polygon has been evaluated separately based on combining values of suitability cultural landscape with index values that creates sensibility characteristics by using matrix method. 
Table 7. Combining sensibility characteristics index value and values of suitability of cultural landscape

\begin{tabular}{|c|c|c|c|c|c|c|c|c|c|c|}
\hline \multirow{3}{*}{\multicolumn{2}{|c|}{ Organic natural landscape }} & \multicolumn{8}{|c|}{ Suitability value } & \multirow{3}{*}{ 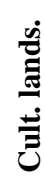 } \\
\hline & & \multicolumn{4}{|c|}{ Residential areas } & \multicolumn{4}{|c|}{ Agricultural areas } & \\
\hline & & $\begin{array}{l}\text { N.S. at all } \\
67-100 \%\end{array}$ & $\begin{array}{l}\text { P.N.S } \\
\text { 34-66\% }\end{array}$ & $\begin{array}{c}\text { N.S } \\
1-33 \%\end{array}$ & $\begin{array}{c}\text { Lea.S } \\
<1 \%\end{array}$ & $\begin{array}{c}\text { L.S } \\
67-100 \%\end{array}$ & $\begin{array}{c}\text { P.S } \\
\text { 34-66\% }\end{array}$ & $\begin{array}{c}\mathrm{S} \\
\mathbf{1 - 3 3 \%}\end{array}$ & $\begin{array}{l}\text { M.S } \\
<1 \%\end{array}$ & \\
\hline \multicolumn{2}{|l|}{ Index value } & -3 & -2 & -1 & $\mathbf{0}$ & 1 & 2 & 3 & 4 & \\
\hline Stony-rocky & 1 & & & & & & & & & \\
\hline Frigana-maki & 2 & & & & & & & & & \\
\hline Forest & 3 & & & & & & & & & \\
\hline \multirow[t]{3}{*}{ Endemic and sensibility } & 4 & 4 & 4 & 4 & 4 & 4 & 4 & 4 & 4 & \\
\hline & & 1 & 2 & 3 & 4 & 5 & 6 & 7 & 8 & \\
\hline & & \multicolumn{2}{|c|}{$\begin{array}{c}\text { "no" scale score } \\
(\text { Table 1) }\end{array}$} & \multicolumn{3}{|c|}{$\begin{array}{c}\text { "partly" scale score } \\
\text { (Table 1) }\end{array}$} & \multicolumn{3}{|c|}{$\begin{array}{c}\text { "yes" scale score } \\
\text { (Table 1) }\end{array}$} & \\
\hline
\end{tabular}

\section{Main findings and argument}

The reason for evaluation each Polygon separately on each table (Tables 9-14) that is determined as "Environments under the protection of the law" (SAPUL) is because each polygon is evaluated based on the scoring of different systems as a result of GIS examination which was explained in the above table.

- Turkish Republic Ministry of Environment and Urban Planning protection commission has specified and mapped 81 polygons as a result of a study. In this study they wanted to specify what kind of status the polygons would have. In order to do so, the polygons, which create sensitive areas that will be protected under GIS environment polling, have been set up based on the point scoring system in the Table 7 and the areas that polygon cover their percentages has been given in Table 8 and mapped in Figure 3.

- The map and the areas that polygons cover, which was specified as sensitive areas that will be protected by the law (SAPUL), are given in Table 9 and Figure 4 based on the point scoring system that belongs to forest areas that has qualifications of usage of landscape.

- The total scoring is given in Table 15, according to qualifications of the forest's ability to renew itself. The index value of the areas, which has the qualifications of forest zone, is given as " 3 " in Table 9.

Table 8. The total areas and the areas the polygons with the status of sensitive areas that will be definitely protected cover based on specifications of usage of landscape and their percentages

\begin{tabular}{c|c|c}
\hline Usage of landscape & Area $\left.\mathbf{( m}^{\mathbf{2}}\right)$ & Area $(\boldsymbol{\%})$ \\
\hline 1 & 152817.90 & $0.55 \%$ \\
2 & 3609881.10 & $12.9 \%$ \\
3 & 22044944.00 & $78.9 \%$ \\
4 & 2133453.70 & $7.6 \%$ \\
\hline Total & $\mathbf{2 7 9 4 1 \mathbf { 0 9 6 . 7 0 }}$ & $\mathbf{1 0 0 . 0 \%}$ \\
\hline
\end{tabular}




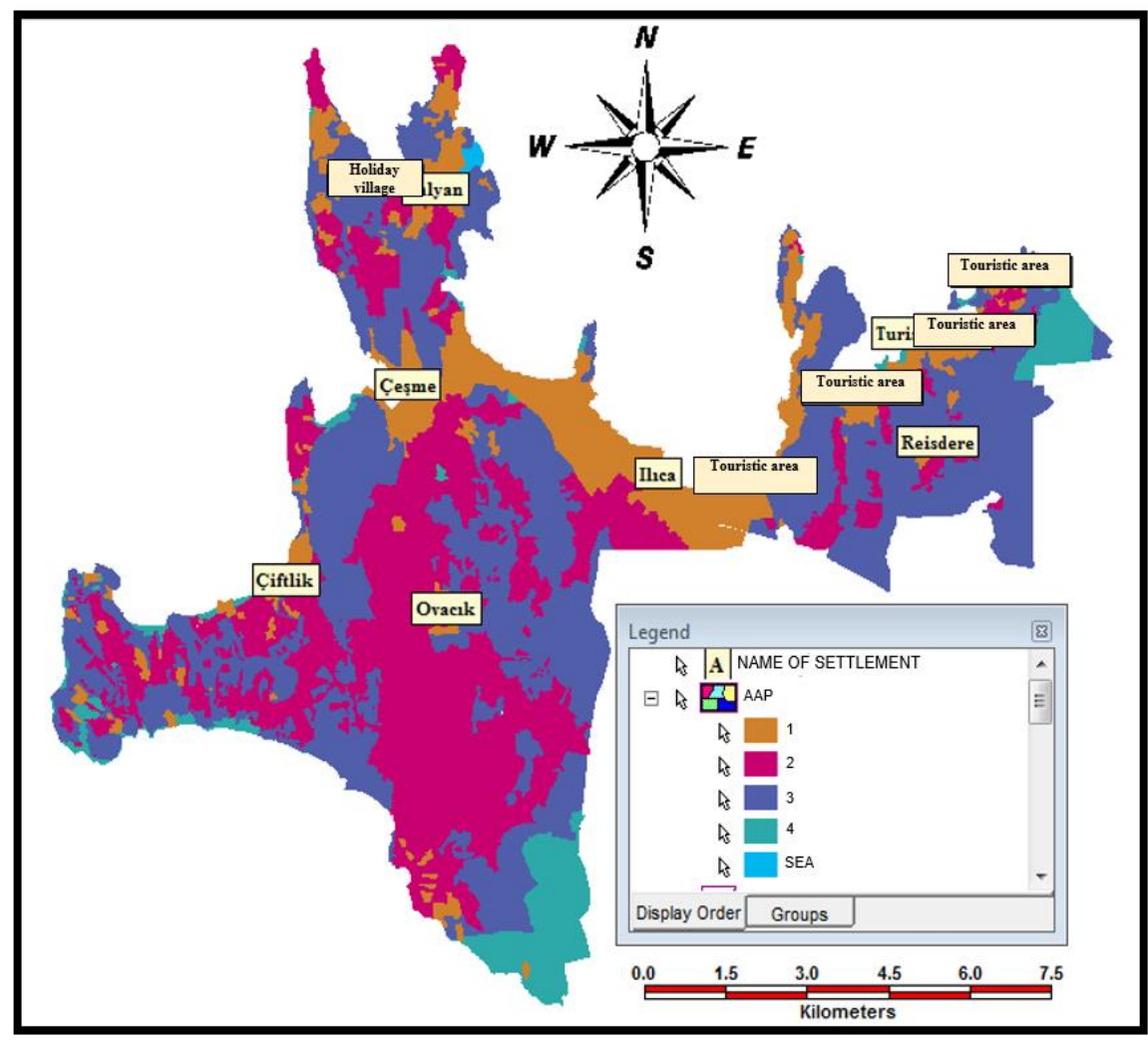

Figure 3. Map belonging to Table 8

Table 9. The areas which polygons with forest qualifications cover among sensitive areas that will be definitely protected

\begin{tabular}{c|c|c}
\hline Polygon number & Protected area number & Area $\left(\mathbf{m}^{\mathbf{2}}\right)$ \\
\hline 1 & SAPUL & 2848752.80 \\
5 & SAPUL & 146900.10 \\
15 & SAPUL & 1949916.20 \\
16 & SAPUL & 808389.20 \\
19 & SAPUL & 254557370.00 \\
20 & SAPUL & 401061.50 \\
22 & SAPUL & 3499518.80 \\
33 & SAPUL & 477665.00 \\
37 & SAPUL & 1377460.00 \\
40 & SAPUL & 1804035.40 \\
46 & SAPUL & 110890.30 \\
48 & SAPUL & 423369.40 \\
51 & SAPUL & 628957.70 \\
57 & SAPUL & 557441.30 \\
66 & SAPUL & 237463.90 \\
70 & SAPUL & 1970311.00 \\
77 & SAPUL & 79142.30 \\
80 & SAPUL & 5901654.40 \\
\hline
\end{tabular}




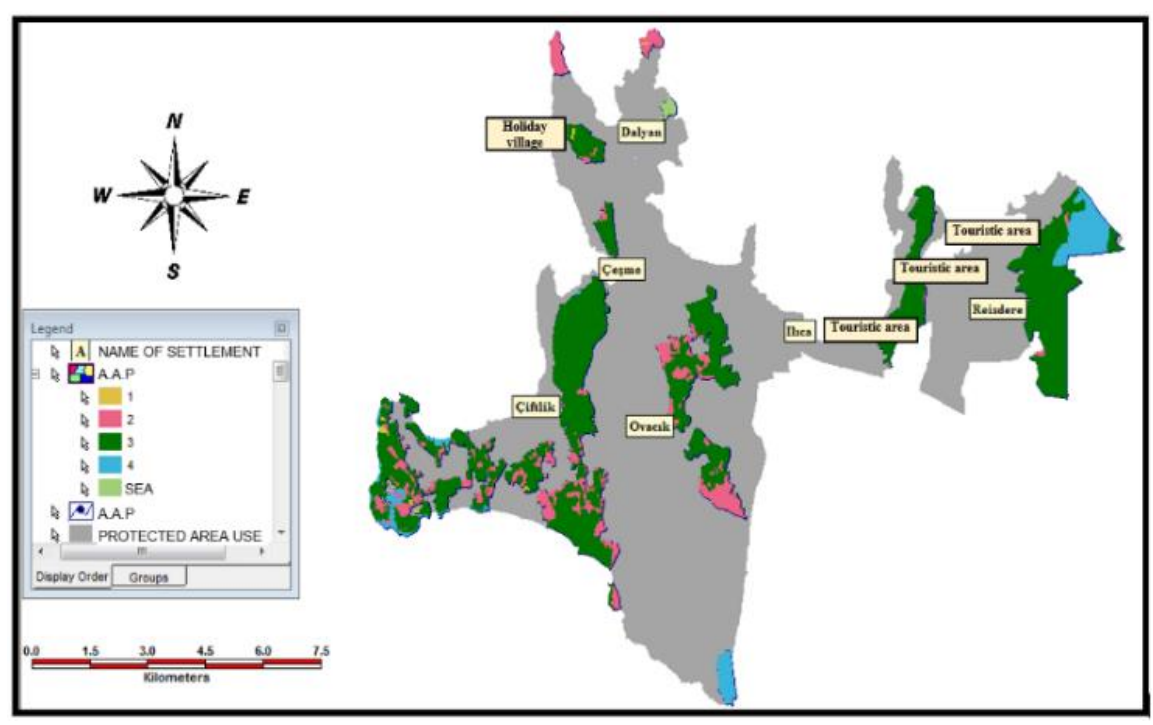

Figure 4. Map belonging to Table 9

- The map of the areas that polygons cover is shown in Table 10 and Figure 5. Those polygons are known as sensitive areas that will be protected by the law according to rare species point scoring system. The total point scoring based on "sensitiveness" characteristic could be seen in Table 15. In Table 10, the index value has been taken as "4" for the polygons with "forest zone" qualification.

- The criterion score has been examined based on models that have been developed on CBS according to these sensitive areas that will be protected by the law. In Table 15:

- Cultural landscape score is evaluated as $\geq 2$. (Considering Table 2: It was considered to make a decision for the index value if the residential areas are less than agricultural areas in polygons).

- Organic landscape score is evaluated as $\geq 7$. (Considering Table 3: Forest formation and endemic-rare species were considered to make a decision for the index value).

- Inorganic landscape score is evaluated as $\geq 3$. (Considering Table 4: At least 3 qualifications that set the criteria of inorganic landscape, were considered to make decision for index value).

- Sensitiveness score is evaluated as $\geq 0$ (Considering Table 7: because the Sensitiveness is evaluated separately, it is not necessary to look for rare endemic species in polygon).

- Renewing itself score is evaluated as $\geq 3$ (Considering Table 6: Forest formation is considered to make decision for the index value in polygons).

- The Map and the area coverage of polygons are shown in Table 11 and Figure 6. Those areas are known as sensitive that will be protected by the law (SAPUL) based on the points of cultural landscape, organic landscape, inorganic landscape and ability of renewing itself on the GIS platform. According to the qualifications given above, the total scoring could be seen in Table 15. Polygons in Table 11, the scores given above are evaluated as index values. 
Table 10. The areas that polygons with characteristic of "sensitiveness" cover. Those areas have the sensitive areas that will have definitely protected characteristics

\begin{tabular}{c|c|c}
\hline Polygon number & Protected area number & Area $\left(\mathbf{m}^{\mathbf{2}}\right)$ \\
\hline 1 & SAPUL & 2848752.80 \\
5 & SAPUL & 146900.10 \\
15 & SAPUL & 1949916.20 \\
16 & SAPUL & 808389.20 \\
19 & SAPUL & 2545573.70 \\
20 & SAPUL & 401061.50 \\
22 & SAPUL & 3499518.80 \\
33 & SAPUL & 477665.00 \\
\hline
\end{tabular}

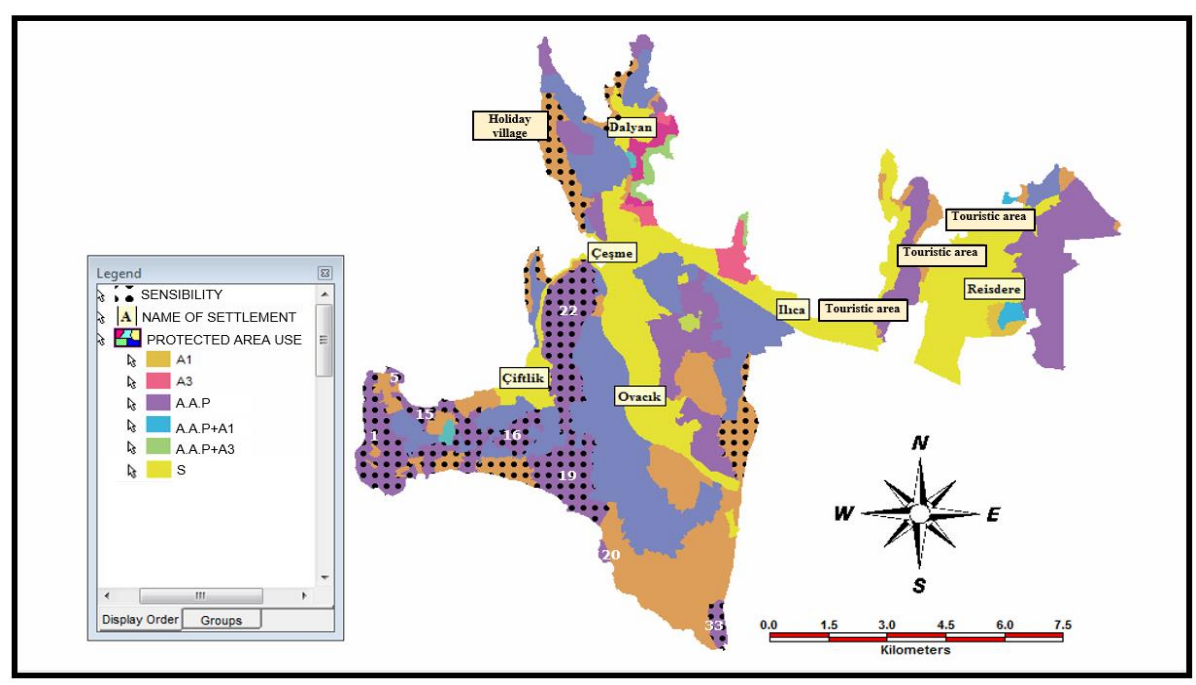

Figure 5. Map belonging to Table 10

Table 11. The areas of polygons with qualifications of cultural landscape, organic, inorganic and ability to renew itself among polygons that are in the areas that will be definitely protected

\begin{tabular}{c|c|c}
\hline Polygon number & Protected area number & Area $\left(\mathbf{m}^{\mathbf{2}}\right)$ \\
\hline 1 & SAPUL & 2848752.80 \\
5 & SAPUL & 146900.10 \\
16 & SAPUL & 808389.20 \\
19 & SAPUL & 2545573.70 \\
22 & SAPUL & 3499518.80 \\
33 & SAPUL & 477665.00 \\
\hline
\end{tabular}




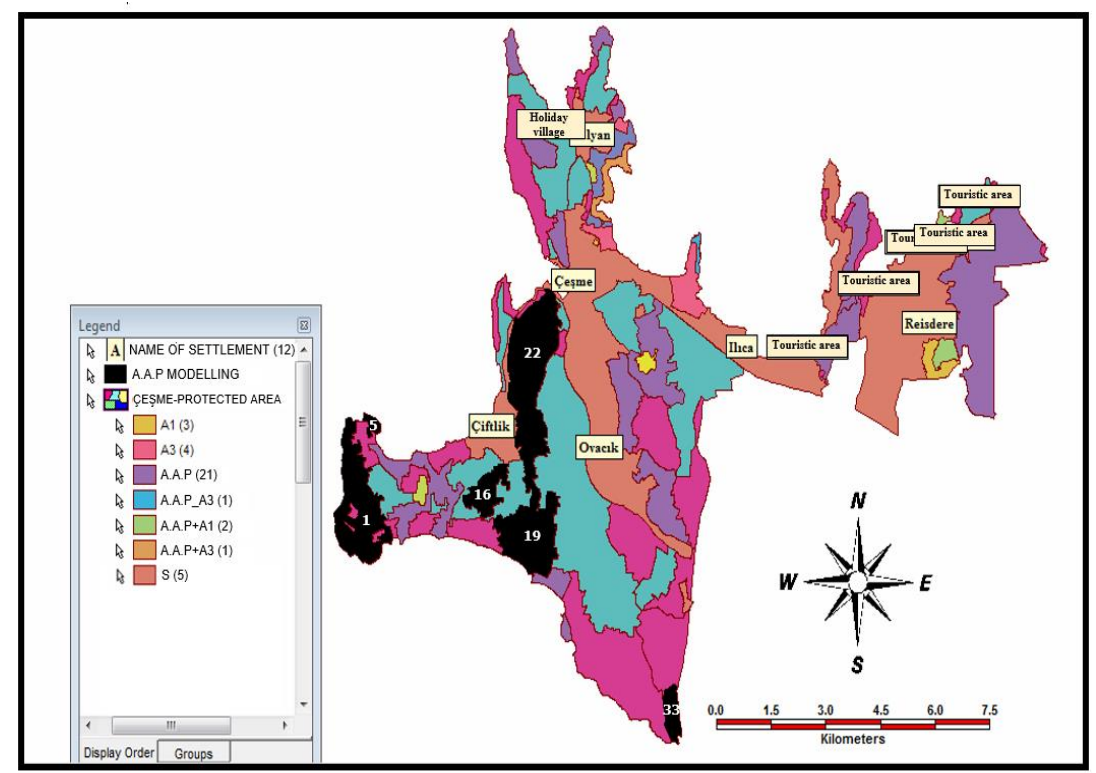

Figure 6. Map belongs to Table 11

- The criterion score has been examined based on models that have been developed on GIS according to these sensitive areas that will be protected by the law. In Table 15

- Cultural landscape score is evaluated as $\geq 3$ (Considering Table 2: residential areas' being so less and absence of agricultural areas are considered to make decision for the index value in polygons).

- Organic landscape score is evaluated as $\geq 3$ (Considering Table 3: forest formation existence is considered to make the decision for index value in polygons).

- Inorganic landscape score is evaluated as $\geq 3$ (Considering Table 4: at least 3 qualifications in inorganic landscape qualification table (Table 4) that set the criteria of inorganic landscape, were considered to make decision for index value).

- Sensitiveness score is evaluated as $\geq 0$ (Considering Table 7: it is not necessary to look for rare endemic species in polygon).

- Historical landscape score is evaluated as $\geq 1$ (Considering Table 5: at least 3 qualifications in historical landscape qualification table (Table 5) that set the criteria of historical landscape, were considered to make decision for index value).

- Renewing itself score is evaluated as $\geq 3$ (Considering Table 6: forest formation is considered to make decision for the index value in polygons).

The Map and the area coverage of polygons are shown in Table 12 and Figure 7. Those areas are known as sensitive areas that will be protected by the law (SAPUL) based on the scores of cultural landscape, organic landscape, inorganic landscape, historical landscape and ability of renewing itself which has specifications of archeological protected areas on the GIS platform. According to the qualifications given above, the total scoring could be seen in Table 15. Polygons in Table 12, the scores given above are evaluated as index values. 


$$
-1044 \text { - }
$$

Table 12. The areas of polygons with qualifications of cultural landscape, organic, inorganic, historical landscape and ability to renew itself among polygons that are in the areas that will be definitely protected

\begin{tabular}{c|c|c}
\hline Polygon number & Protected area number & Area $\left(\mathbf{m}^{\mathbf{2}}\right)$ \\
\hline 46 & SAPUL & 110890.30 \\
57 & SAPUL & 557441.30 \\
77 & SAPUL & 79142.30 \\
\hline & Total & $\mathbf{7 4 7 4 7 3 . 9 0}$ \\
\hline
\end{tabular}

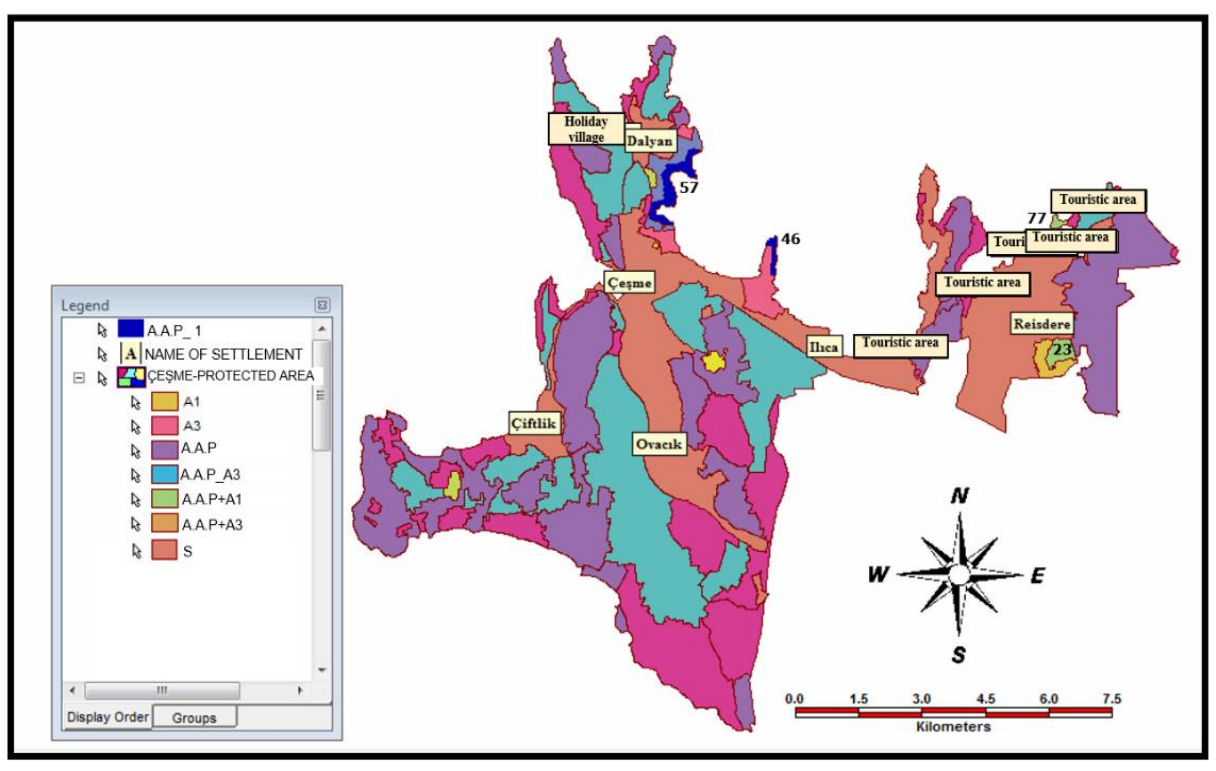

Figure 7. Map belonging to Table 12

- The criterion score has been examined based on models that have been developed on GIS according to these sensitive areas that will be protected by the law. In Table 15

- Cultural landscape score is evaluated as $\geq 3$ (Considering Table 2: residential areas' being so less and absence of agricultural areas are effective to make decision for the index value in polygons)

- Organic landscape score is evaluated as $\geq 3$ (Considering Table 3: forest formation existence is considered to make the decision for index value in polygons).

- Inorganic landscape score is evaluated as $\geq 3$ (Considering Table 4: at least 3 qualifications in inorganic landscape qualification table (Table 4) that set the criteria of inorganic landscape, were considered to make decision for index value).

- Sensitiveness score is evaluated as $\geq 0$ (Considering Table 7: it is not necessary to look for rare endemic species in polygon).

- Renewing itself score is evaluated as $\geq 3$ (Considering Table 6: forest formation is considered to make decision for the index value in polygons). 


$$
-1045-
$$

The Map and the area coverage of polygons are shown in Table 13 and Figure 8. Those areas are known as sensitive areas that will be protected by the law (SAPUL) based on the scores of cultural landscape, organic landscape, inorganic landscape and ability of renewing itself on the GIS platform. According to the qualifications given above, the total scoring could be seen in Table 15. Polygons in Table 13, the scores given above are evaluated as index values.

Table 13. The areas of polygons with qualifications of cultural landscape, organic, inorganic, and ability to renew itself among polygons that are in the areas that will be definitely protected

\begin{tabular}{c|c|c}
\hline Polygon number & Protected area number & Area $\left(\mathbf{m}^{\mathbf{2}}\right)$ \\
\hline 5 & SAPUL & 146900.10 \\
15 & SAPUL & 1949916.20 \\
19 & SAPUL & 2545573.70 \\
20 & SAPUL & 401061.50 \\
33 & SAPUL & 477665.00 \\
40 & SAPUL & 1804035.40 \\
46 & SAPUL & 110890.30 \\
48 & SAPUL & 423369.40 \\
53 & SAPUL & 304164.50 \\
57 & SAPUL & 557441.30 \\
77 & SAPUL & 79142.30 \\
80 & SAPUL & 5901654.40 \\
\hline
\end{tabular}

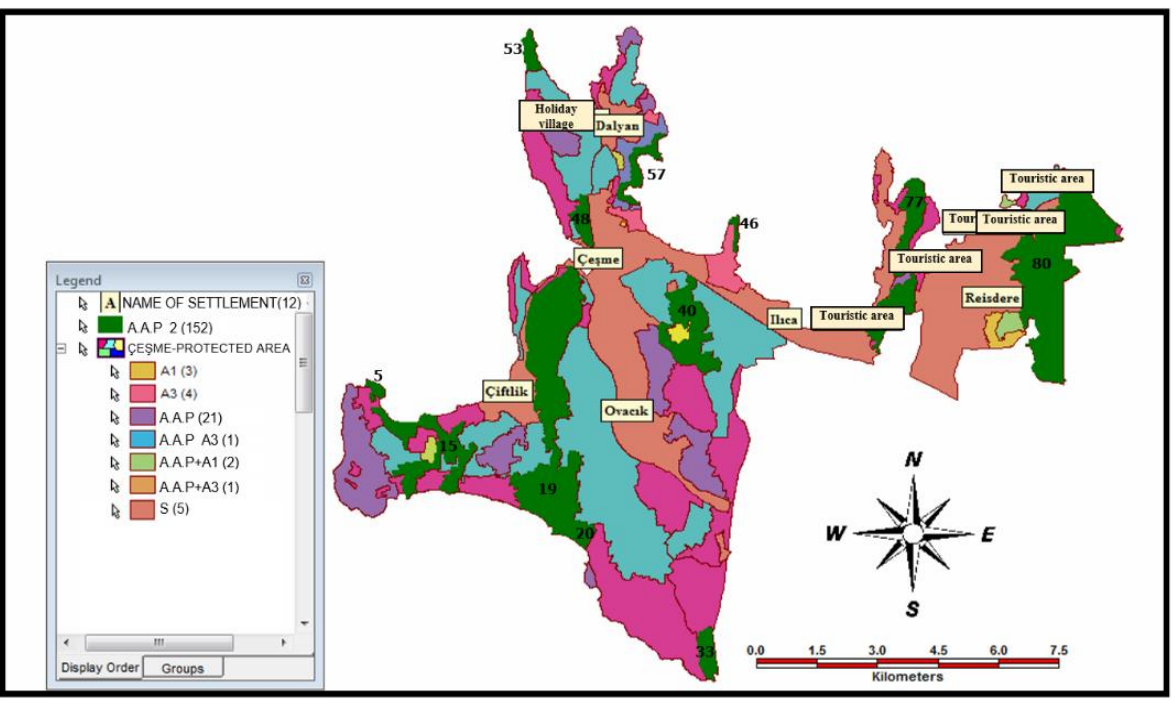

Figure 8. Map belonging to Table 13

- The criterion score has been examined based on models that have been developed on CBS according to these sensitive areas that will be protected by the law. In Table 15 
- Cultural landscape score is evaluated as $\geq 3$ (Considering Table 2: residential areas' being so less and absence of agricultural areas are considered to make decision for the index value in polygons)

- Organic landscape score is evaluated as $\geq 3$ (Considering Table 3: forest formation existence considered to make the decision for index value in polygons).

- Inorganic landscape score is evaluated as $\geq 3$ (Considering Table 4: at least 3 qualifications in inorganic landscape qualification table (Table 4) that set the criteria of inorganic landscape, were considered to make decision for index value).

- Sensitiveness score is evaluated as $\geq 4$ (Considering Table 7: it was researched if there was rare endemic species in polygon).

- Ability of renewing itself score is evaluated as $\geq 3$ (Considering Table 6: forest formation is considered to make decision for the index value in polygons).

The Map and the area coverage of polygons are shown in Table 14 and Figure 9. Those areas are known as sensitive areas that will be protected by the law (SAPUL) based on the scores of cultural landscape, organic landscape, inorganic landscape, sensitiveness and ability of renewing itself on the GIS platform. According to the qualifications given above, the total scoring could be seen in Table 15. Polygons in Table 14, the scores given above are evaluated as index values.

Table 14. The areas of polygons with qualifications of cultural landscape, organic, inorganic, sensitiveness and ability to renew itself among polygons that are in the areas that will be definitely protected

\begin{tabular}{c|c|c}
\hline Polygon number & Protected area number & Area $\left(\mathbf{m}^{\mathbf{2}}\right)$ \\
\hline 5 & SAPUL & 146900.10 \\
15 & SAPUL & 1949916.20 \\
19 & SAPUL & 2545573.70 \\
20 & SAPUL & 401061.50 \\
22 & SAPUL & 3499518.80 \\
33 & SAPUL & 477665.00 \\
\hline & Total & $\mathbf{9 0 2 0 6 3 5 . 3 0}$ \\
\hline
\end{tabular}

Table 15 has been generated by obtaining usage of areas according to satellite visuals and based on the tables above scoring qualifications of "cultural, organic, inorganic, historical landscape and ability of renewing itself. Landscape criteria values have been evaluated based on the database of GIS (Geomedia). As a result of modeling done above, polygons mentioned in Tables 9-14 have come forth and Table 15 has been created. Table 15, landscape criteria score mirrors landscape criteria scores of 20 polygons among 81 polygons that has been specified as sensitive areas and will be protected by the law (SAPUL) by Protection Commission of the Ministry of Environment and Urban Planning. As a result, the "suggested map of natural protected areas" has been created Figure 10. 


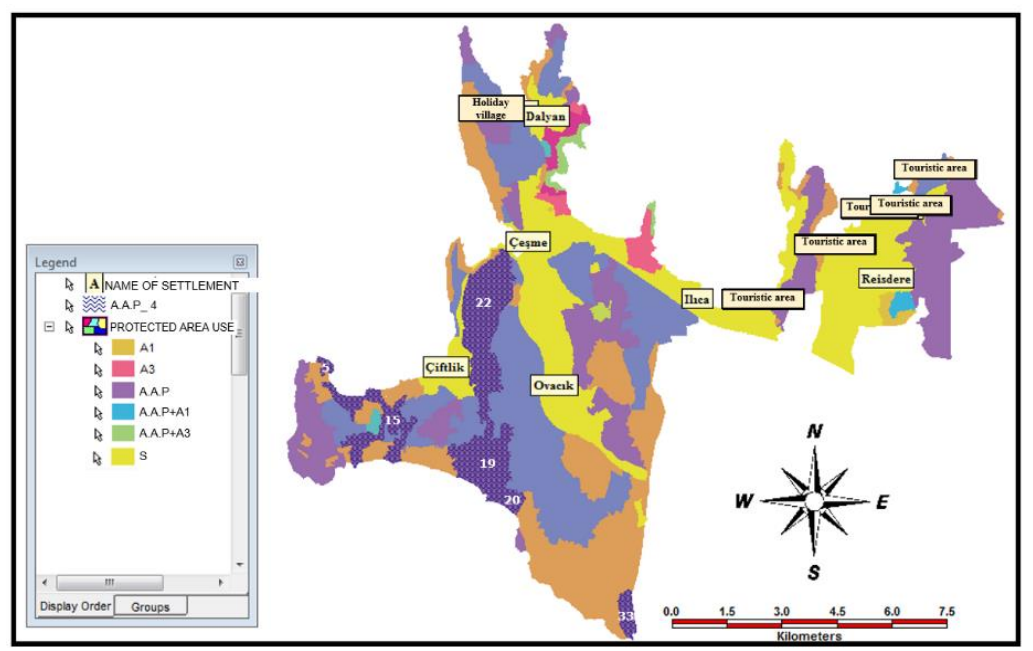

Figure 9. Map belonging to Table 14

Table 15. Distribution of landscape criteria scores of sensitivity of the areas that will be definitely protected

\begin{tabular}{|c|c|c|c|c|c|c|c|c|c|c|c|c|c|c|c|c|c|c|c|c|}
\hline \multirow{2}{*}{ Landscape criteria } & \multicolumn{20}{|c|}{ Polygon numbers } \\
\hline & 1 & 5 & 15 & 16 & 19 & 20 & 22 & 33 & 37 & 40 & 46 & 48 & 51 & 53 & 57 & 66 & 70 & 73 & 77 & 80 \\
\hline & 2 & 4 & 2 & 2 & 3 & 3 & 3 & 4 & 2 & 3 & 3 & 3 & 2 & 4 & 3 & 2 & 4 & 4 & 4 & 4 \\
\hline Organic landsc & 10 & 9 & 10 & 9 & 10 & 6 & 12 & 9 & 5 & 5 & 5 & 5 & 5 & 3 & 3 & 5 & 5 & 2 & 3 & 3 \\
\hline & 4 & 4 & 5 & 3 & 5 & 5 & 5 & 4 & 3 & 3 & 4 & 3 & 3 & 4 & 4 & 4 & 4 & 3 & 3 & 4 \\
\hline His & 0 & 0 & 0 & 0 & 0 & 0 & 0 & 0 & 0 & 0 & 2 & 0 & 0 & 0 & 2 & 0 & 0 & 0 & 2 & 0 \\
\hline Ahility to renew itcelf & 6 & 5 & 6 & 6 & 6 & 3 & 8 & 5 & 6 & 6 & 5 & 6 & 6 & 3 & 3 & 6 & 6 & 2 & 2 & 3 \\
\hline Sensitiveness & 4 & 4 & 4 & 4 & 4 & 4 & 4 & 4 & 0 & 0 & 0 & 0 & 0 & 0 & 0 & 0 & 0 & 0 & 0 & 0 \\
\hline
\end{tabular}

\section{Results and suggestions}

The scores of cultural, organic, inorganic, historical landscape and ability of renewing itself and sensitivity of the areas that will be protected by the law has been presented based on the area usage status which has been evaluated on GIS platform by the Protection Commission of the Ministry of Environment and Urban Planning in order to finalize the legal decisions about natural protection fast and accurate. As a result of the examinations that have been made above (modellings), 20 polygons, which will be evaluated as sensitive areas that will be protected by the law in 5 different maps have been appeared. Those maps have been appeared based on the charts. The polygons known as sensitive areas that will be protected by the law (SAPUL) is classified based on their types of the area usage. According to this:

- Areas of Cesme district is covered by residential areas $0.54 \%$, agricultural areas $12.82 \%$, scrub + garrigue + forest $78.27 \%$, lithosolic + garrigue $7.58 \%$. Scrub + garrigue + forest areas are $22.044 .944 .00 \mathrm{~m}^{2}$ which is $11.79 \%$ of Cesme district's square measure.

- According to the result map of ability to renew itself only in $73^{\text {rd }}$ polygon there is no forest area. But this $73^{\text {rd }}$ polygon establishes a buffer zone between other polygons that has the protection status. 
- According to the sensitiveness map; in the forest areas in $1^{\text {st }}, 5^{\text {th }}, 15^{\text {th }}, 16^{\text {th }}, 19^{\text {th }}$, $20^{\text {th }}, 22^{\text {nd }}, 23^{\text {rd }}$ polygons, there are "Juniperus oxycedrus subs. Macrocarpa" (large size fruited bushy juniper) and Pistacia lentiscus. Also there are Chia (gumwood) in enough quantity. According to this map the areas with sensitive qualifications covers $54.84 \%$ in the polygons that have been determined as scrub + garrigue + forest sensitive areas that will be protected by the law (SAPUL).

- In the given maps in Figures 4-8 and examined models, according to the evaluation which has been done based on the landscape criteria scores, 20 polygons have been determined as sensitive areas that will be protected by the law (SAPUL) (Fig. 10; Table 15).

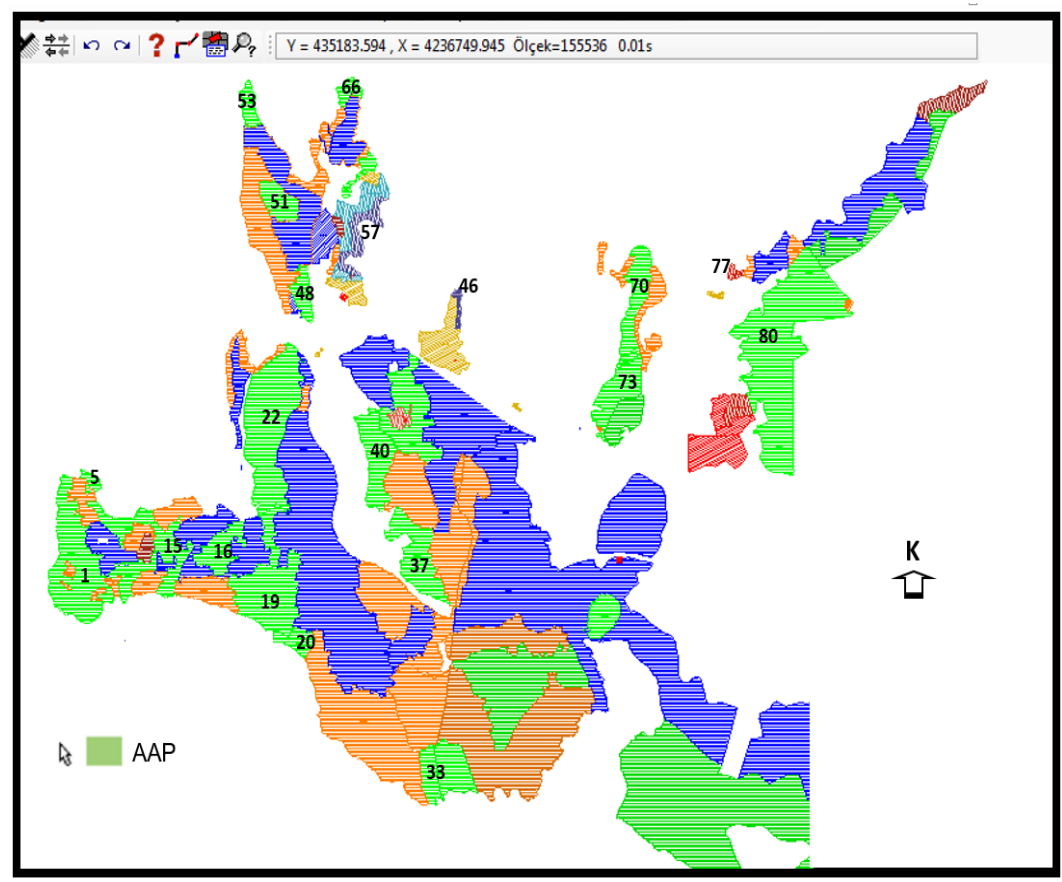

Figure 10. The map that shows the sensitive areas that will be protected by the law

It is aimed to suggest natural protected area mapping method supported by geographical information system which is based on true and scientific information in order to generate the maps of natural protected areas that are supposed to be prepared by the Cultural and Natural Heritage Preservation Board affiliated with the Ministry of Environment and Urban Planning. The results of the applications that will be obtained after the research studies are completed in Cesme district, will allow building a source and data to prevent disoperation which are still being applied. It is hoped that it will be an accurate and objective guiding method for the maps of natural protected areas that are supposed to be prepared by the Cultural and Natural Heritage Preservation Board affiliated with the Ministry of Environment and Urban Planning in Turkey as well as the other related institutions and organizations around the world.

Acknowledgements. This article has been produced based on Funda ANKAYA'S doctoral thesis “The analysis of the natural protected areas in terms of landscape criteria in Çeşme district, province of İzmir”. 


\section{REFERENCES}

[1] Anonymous (2019a): https://www.google.com.tr/maps/search 1\%C3\%A7e\%C5\%9Fme+s\%C4\%B1n\%C4\%B1rlar\%C4\%B1/@38.3208098,26.2268388, 12z/data $=! 3 \mathrm{~m} 1 ! 4 \mathrm{~b} 1$. - Date accessed: 30.09.2019.

[2] Anonymous (2019b): https://www.nufusu.com/ilce/cesme_izmir-nufusu. - Date accessed: 30.09.2019.

[3] Buchwald, K. (1980): Aufgabenstellung ökologisch-gestalterischer Planungen im Rahmen umfassender Umweltplanung. Handbuch für Planung, Gestaltung und Schutz der Umwelt. Band 3. - BLV, München, pp. 1-126.

[4] Caner, G. (2007): National and International Nature Conservation Criteria and Natura 2000. - Master Thesis, Department of City and Regional Planning. Y1ldız Teknik University, Graduate School of Science and Enginnering, İstanbul.

[5] Çolak, A. H. (2001): Nature Conservation in Forest. - National Parks Game and Wildlife General Directorate Publication, Ankara.

[6] Frederic, O., et al. (1988): Classification of natural areas for planning. - Journal of Soil and Water Conservation, Department of Agricultural and Resource Economics, University of Vermont, Burlington.

[7] Green, B. (1985): Countryside Conservation: The Protection and Management of Amenity Ecosystems. - Geroge Allen \& Unwin London.

[8] Gülez, S. (1984): Classification of natural monuments. - Journal of Nature and Human 18(1).

[9] Gülez, S. (1990): An Assessment Method Developed for the Determination of Forest Recreational Potential. Istanbul University Journal of the Faculty of Forestry, 40 (2).

[10] Heydemann, B. (1981): Zur Frage der Flaechengrösse von Biotopbestaenden für den Arten- und Ökosystemschutz. - Jahrbuch für Nazturschutz und Landschaftspflege. Heft 31. Kilda Verlag, Greven, pp. 21-51.

[11] Kinnon, M., et al. (1986): Managing Protected Areas in the Tropics. - International Union for Conservation of Nature and Natural Resources and the United Nations Environment Programme, Gland, Switzerland.

[12] Mumcu, E. (2009): A Research on Landscape Planning in Protected Areas in Italy: The Case of Boretto. - Master Thesis. Ankara University, Institute of Natural and Applied Sciences, Ankara.

[13] Özer, S. (2004): Investigation of Sarıkamış (Kars) Forests in Terms of Nature Conservation Criteria. - PhD Thesis, Department of Landscape Architecture. Atatürk University, Institute of Natural and Applied Sciences, Erzurum.

[14] Türky1lmaz, B. (1991): Turkey in the field of nature conservation and natural sites of identifying and determining the criteria to be used in order to classify Izmir/Kemalpasa research-based methods of sampling". - Dissertation, Bornova-Izmir. Ege University, Institute of Natural and Applied Sciences, Department of Landscape Architecture, İzmir.

[15] Türkyılmaz, B., Kurucu, Y., Altınbaş, Ü., Bolca, M., Esetlili, T., Özen, F., Gülgün, B., Gencer, G., Güney, A., Hepcan, Ş., Özden, N. (2005): Usability of Geographical Information System in Determination and Classification of Natural Sites and Researches on Creating a Database in a Sampling Area (Kaynaklar -Izmir). - Project No: 102 Y 046.

[16] Uzun, O., Müderrisoğlu, H. (2010): Visual Landscape Quality in Landscape Planning: Examples of Kars and Ardahan Cities in Turkey. - Department of Landscape Architecture, Faculty of Forestry, Düzce University, Düzce, Turkey.

[17] Yazici, K., Gülgün Aslan, B., Ankaya, F. (2017): Function of landscape scenery areas; a case study on Van Province. - Karabuk University Journal of the Institute of Social Sciences Special Issue: 168-176.

[18] Yazici, K., Gülgün Aslan, B. (2018a): GIS Using Multi-Criteria Decision Analysis for Assessment and Map-Based Indicators for Nursery Garden Management. - IJEES 8(2): 415-428. 
[19] Yazici, K., Kalaycı Önaç, A., Gülgün Aslan, B. (2018b): The Importance of UAV (Drone) Usage According to Landscape Architecture. - International Marmara Science and Social Sciences Congress 2018, Kocaeli, Turkey, pp. 1416-1426 (full text paper/oral presentation).

[20] Yenilmez Arpa, N., Gülgün Aslan, B., Yazici, K. (2016): Designation of the trails and routs for visitor management in the protected areas case on Göreme Historical National Park in Turkey. - 6th International Conference of Ecosystems, Tirana, Albania, 2-6 June (ICE 2016).

[21] Yücel, M. (1995): Nature Conservation Areas and Planning. - Ç. Ü. Faculty of Agriculture Publications, Adana. 